\title{
DETOXIFICATION OF AFLATOXIN CONTAMINATED RATION BY CHEMICAL, BIOLOGICAL AND SPICES METHODS IN NILE TILAPIA (OREOCHROMIS NILOTICUS) DIETS
}

\author{
Magouz $^{1}$ F. I., Eweedah ${ }^{1}$, N. M., Salem ${ }^{2}$, M. F. E. and A. A. \\ Amer $^{2}$ \\ 1- Department of Animal Prod., Fac. Agric., Kafr El-Sheikh, Univ. \\ 2-Central Laboratory for Aquaculture Research-Abbassa, Aquaculture \\ Research Unit, Sakha
}

\begin{abstract}
This study was done to investigate the toxic effects of aflatoxin B1 (AFB1) on Nile tilapia (Oreochromis niloticus) fingerlings and detoxifying these drastic effects by using some antimycotoxins. Therefore, 0.5 and $1 \mathrm{~g}$ of each Black pepper, Filofeed plus and Cap $T_{2}$ were added to an aflatoxin diet (150 $\mathrm{ppb}$ ) for fingerlings. These diets were offered 6 days a week at $3 \%$ daily of actual biomass in glass aquaria (three aquaria / treatment) in the wet Lab. The experiment lasted for 14 weeks (98 days). The Aflatoxic diet had adversely affected growth performance, survival rate, feed and protein utilization, muscular and abdominal areas and carcass composition of fish as well as residues of AFB1 (ppb) was observed in the viscera and muscles of fish. The addition of antitoxins alleviated aflatoxicosis of fish, moreover, it improved all the above tested parameters. Generally, the results obtained of this study recommended that adding 0.5 or $1 \mathrm{~g}$ of Black pepper, Filofeed plus and Cap $\mathrm{T}_{2}$ as fish feed additives could be used as detoxifying agents for aflatoxin.
\end{abstract}

Key words: Tilapia- aflatoxin B1- antimycotoxins- Black pepper Filofeed plus - Cap T2- growth performance

\section{INTRODUCTION}

Tilapia is the third most important cultured fish group in the world, after carps and salmonids (FAO, 2002). Tilapia production has increased greatly in the past two decades and world production of farmed tilapia exceeded two million metric tons in 2004.Tilapia are currently raised in different types of production systems ranging from pond, tank, cage, flowing water and intensive water reuse culture systems. (El Sayed et al., 2005).

The intensification of aquaculture and globalization of the seafood trade have led to remarkable developments in the aquaculture industry. The global aquaculture industry currently accounts for over $45 \%$ of all seafood consumed. That figure has been projected to increase to 75\% over the next 20 years (FTU, 2007). In Egypt, fish 
production from aquaculture represented about $60 \%$ of total fish production sources (GAFRD, 2007).

The mycotoxigenic fungi involved with the human food chain belong mainly to three genera: Aspergillus, Fusarium and Pencillium. While Fusarium species are destructive plant pathogens producing mycotoxin before, or immediately post harvesting, Penicillium and Aspergillus species are more commonly found as contaminants of commodities and foods during drying and subsequent storage (Abdelhamid, 1989 and Sweeney and Dobson, 1998). Also, Farr et al. (1989) added that Aspergillus flavus and Aspergillus Parasiticus are important contaminants of certain foods and animal feeds because of their ability to produce aflatoxin.

Aflatoxins are considered the most carcinogenic, mutagenic and teratogenic poisonous by - product of the growth of the molds Aspergillus flavus and Aspergillus parasiticus, are the most studied and widely known mycotoxins. There are four major groups of aflatoxins: B1, B2, G1 and G2. Aflatoxins M1, a metabolite of aflatoxins B1 in mammals, may be found in the milk of animals eating feeds contaminated by Aflatoxins B1(Conner, 1993 and FAO, 2002). Aflatoxins B1, B2, G1 and G2 are classified as Group1 human carcinogens whereas M1 is classified as Group 2 probable human carcinogen (loannou - Kakouri et al., 1999).

Aflatoxins are a major contaminant in aqua feeds and considered as a causative agent for fish mortality, morbidity and low productivity besides its residues in fish carcass leading to economic losses, human toxicity and affects public health specially in Egypt (EI Fiky and Zaki, 1994; Abdelhamid and Saleh, 1996; and Abdelhamid et al., 1998). Practically, it is not possible to destroy the contaminated feed, therefore to prevent aflatoxicosis in fish, increasing animal immunity (Zaky et al., 2000 and Sahoo and Mukherjee, 2003) and detoxification chemically (CAST, 2003) or biologically (Nayek et al., 2007) were used.

Therefore, the present work aimed to study the drastic effect of AFB1 on the growth performance, survivability, nutrient utilization, some organs indices, carcass composition, residues of AFB1, and muscular and abdominal areas of the experimental fish Nile tilapia $(O$. niloticus) fingerlings. Also, this study was conducted to evaluate the ability of some nutritional agents, namely Black pepper (as spices additives), Filofeed plus (as chemicals additives) and Cap T2 (as biological additives) at levels of 0.5 and $1 \mathrm{~g}$ from each to detoxify the drastic effects of this dangerous toxin AFB1 on Nile tilapia fish. 
MATERIALS AND METHODS

The present study was carried out at the fish lab, Sakha Aquaculture Research Unit, Central Laboratory for Aquaculture Research-Abbassa, during summer season 2014. Feeding experiment was conducted for 14 weeks.

\section{1- Experimental fish:}

The experimental fish, (Oreochromis niloticus), were collected from a private farm in EL-Riyadh, Kafr El-Sheikh governorate. The experiment started in August 2014 and lasted up to November 2014. The fingerlings were placed in a fiberglass tank and randomly distributed into the experimental aquaria for the adaptation to the experimental conditions until starting the experiment. Fish were fed the control diet for two weeks, during this period, healthy fish at the same weight replaced the died one.

\section{Experimental design of rearing fish :}

A group of 408 Nile tilapia fingerlings (O. niloticus) fish with an average initial body weight $20 \mathrm{~g}$ were randomly allotted into 24 glass aquaria $(80 \times 35 \times 40 \mathrm{~cm})$, with 17 fish in each aquarium and each treatment was applied in three aquaria. Fresh tap water was stored in fiberglass tanks for $24 \mathrm{~h}$ under aeration for dechlorination. One third of the water in each aquarium was replaced daily and totally changed once every week after removing the wastes. 24 air stones were used for aerating the water aquaria. Water temperature ranged between 24 and $29{ }^{\circ} \mathrm{C}$. Photoperiod was adjusted to be $14 \mathrm{~h}$ light and $10 \mathrm{~h}$ darkness using florescent light. Fish feces and feed residue were removed daily by siphoning.

\section{3- Experimental diets and feeding regime:}

Two weeks before the beginning of the experimental trial, about the fishes were adapted to a basal diet containing $30 \%$ crude protein and consisted of fish meal, soybean meal, yellow corn, wheat bran, corn gluten meal, di - ca - phosphate, sunflower oil and Vit.\& Min mixture. Toxin $\mathrm{AFB}_{1}$ was added at a concentration of $150 \mathrm{ppb}$ to all the experimental diets except the control. Anti-toxin was added at a concentration of 0.5 and $1 \mathrm{~g} / \mathrm{kg}$ to the diets T3, T4, T5, T6, T7 and T8 as shown in Table 1. These ingredients were mixed well and pressed through manufacturing machine (pellets size $1 \mathrm{~mm}$ ). The ingredients and supplements were bought from the local market, but aflatoxin $B_{1}$ was produced through pellets fermentation according to the method described by Abdelhamid and Mahmoud (1996).

\section{4- Experimental dietary additives:}

Table 1.

Formulation of the control and experimental diets are shown in 
The required amount of the diet was prepared every two weeks and stored in a refrigerator until use. The pellets were dried under room temperature for $24 \mathrm{~h}$ before use.

Table 1: Formulation of the control and experimental diets $\%$

\begin{tabular}{|c|c|c|c|c|c|c|c|c|}
\hline Ingredients & $\mathbf{T}_{\mathbf{1}}$ & $\mathbf{T}_{\mathbf{2}}$ & $\mathbf{T 3}$ & $\mathbf{T 4}$ & $\mathbf{T 5}$ & $\mathbf{T 6}$ & $\mathbf{T 7}$ & $\mathbf{T}$ \\
\hline \hline Fish meal & 11 & 11 & 11 & 11 & 11 & 11 & 11 & 11 \\
\hline Soybean meal & 35 & 35 & 35 & 35 & 35 & 35 & 35 & 35 \\
\hline Yellow corn & 32 & 32 & 32 & 32 & 32 & 32 & 32 & 32 \\
\hline Wheat bran & 12 & 12 & 12 & 12 & 12 & 12 & 12 & 12 \\
\hline Corn glutein meal & 5 & 5 & 5 & 5 & 5 & 5 & 5 & 5 \\
\hline Sunflower oil & 3 & 3 & 3 & 3 & 3 & 3 & 3 & 3 \\
\hline Ca phosphate & 1 & & 1 & 1 & 1 & 1 & 1 & 1 \\
\hline Vit.\&Min. mixture* & 1 & & 1 & 1 & 1 & 1 & 1 & 1 \\
\hline Total & 100 & 100 & 100 & 100 & 100 & 100 & 100 & 100 \\
\hline Aflatoxin B1(ppb) & - & 150 & 150 & 150 & 150 & 150 & 150 & 150 \\
\hline Black pepper (g) & - & - & 0.5 & 1 & - & - & - & - \\
\hline Filo feed plus (g) & - & - & - & - & 0.5 & 1 & - & - \\
\hline Cap T2 (g) & - & - & - & - & - & - & 0.5 & 1 \\
\hline
\end{tabular}

*Vitamins and minerals premix (product of Victoir) each $3 \mathrm{~kg}$ contain: 12.00 .000 IU Vit. A ; 3.00 .000 IU Vit. D3; 700 mg Vit. E; 500 mg Vit. K3; 500 mg Vit. B1; 200 mg Vit. B2; $600 \mathrm{mg}$ Vit. B6; $3000 \mu \mathrm{g}$ Vit. B12; 450 mg Vit. C; $3000 \mu \mathrm{g}$ Niacin; $3000 \mathrm{mg}$ Methionine; $10000 \mathrm{mg}$ Choline Chloride; $600 \mu \mathrm{g}$ Biotin; $300 \mathrm{mg}$ Folic acid; $670 \mathrm{mg}$ Pantothenic acid; $3000 \mathrm{mg}$ Magnesium Sulphate; $1800 \mathrm{mg}$ Zinc Sulphate; $10000 \mathrm{mg}$ Iron Sulphate; $3000 \mathrm{mg}$ Copper Sulphate; 300 mg Cobalt Sulphate.

Fish in all treatments were daily fed the experimental diets at a level of $3 \%$ of the body weight, the amount of the feed was given six days a week at two times daily (8a.m and 2p.m) for 14 weeks. Fish were weighed bi-weekly and feed amounts were adjusted according to the new weight.

\section{-Analytical methods:}

\section{1-Water quality analysis:}

Water samples from each aquarium were taken bi-weekly to determine the values of $\mathrm{pH}$, dissolved oxygen, nitrite, ammonia concentration and temperature.

\subsection{1-Temperature:}

Water temperature in degree centigrade was recorded every day by using a thermometer.

\subsection{2- $\mathrm{PH}$ value:}

$\mathrm{PH}$ value of water was monitored using $\mathrm{pH}$ meter (Model DigitSense, Cole - Parmer Instruments Co. Vernon Hills, IL. USA.).

\subsection{3- Dissolved oxygen:}

Dissolved oxygen was measured digitally using an oxygen meter (Model FE 247, EDT Instruments LTD. Dover Kent, and UK). 


\subsection{4-Ammonia $\left(\mathrm{NH}_{3}\right)$ and Nitrite $\left(\mathrm{NO}_{2}\right)$ :}

Ammonia and nitrite were estimated using test kits by Diamond, Diagnostic, Egypt (Model NI, Cat. NO. 22669-00, Hach CO.).

4.2- Proximate analysis of the experimental diets and fish body:

Chemical composition of the control, experimental diets and fish body was at the start and at the end of the experiment carried out according to the methods described by A.OA.C. (1995).

At the end of the experiment, five fish were derived from each group for drying at $60^{\circ} \mathrm{C}$ for 48 hours and then milled through electrical mill and stored in deep freezer until analysis.

\section{5-Growth performance and efficiency of feed and protein utilization:}

The growth performance and feed utilization parameters were calculated according to the following equations:

- Total weight gain (TWG):

TWG $=$ final weight $(g)$ - initial weight $(g)$

- Average daily gain (ADG):

ADG $(\mathrm{g})=$ TWG $(\mathrm{g}) /$ Time (days)

- Survival rate (SR \%):

SR $\%=$ Total number of fish at the end of the experimental $\times 100 /$ total number of fish at the start of the experiment.

- Specific growth rate (SGR, \% / day):

$\mathrm{SGR}=100 \times[\ln w t 1-\ln \mathrm{wt} 0 / \mathrm{T}]$

\section{Whereas:}

In: Natural log.

Wt1: Final weight $(\mathrm{g})$

Wt0: Initial weight $(\mathrm{g})$

$\mathrm{T}$ : Time in days

- Feed conversion ratio (FCR):

$\mathrm{FCR}=$ Total feed consumption (g) / Weight gain (g)

- Feed efficiency (FE):

$\mathrm{FE}=$ Body weight gain $(\mathrm{g}) /$ Feed intake $(\mathrm{g})$

- Protein efficiency ratio (PER):

PER = Body weight gain $(\mathrm{g}) /$ protein intake $(\mathrm{g})$

- Productive protein value (PPV \%)

PPV\% $=100 \times$ [Retained protein $(\mathrm{g}) /$ protein intake $]$

6- Internal Organs Indices:

All fish were killed at the end of the experiment, and soon the abdominal cavity was opened to remove liver, kidney and spleen which were weighed individually. Hepatic somatic index (HSI), kidney somatic index $(\mathrm{KSI})$, and spleen somatic index (SSI) were calculated as follow:

-HSI=Liver weight $\times 100$ / fish weight (Jangaard et al., 1967).

-KSI = kidney weight $\times 100 /$ fish weight (Alabaster and Lioyd, 1982). 
-SSI = spleen weight $\times 100 /$ fish weight (Jangaard et al., 1967).

\section{7- Muscular and abdominal areas:}

The fish were examined also for infiltration / muscular areas using Echo Scan (H5/s) Ultrasonic Diagnostic Instrument, Budapest Remeny Co. according to Salem, (2008).

\section{8- Residues of aflatoxin in the liver and muscle of Tilapia niloticus:}

Liver and muscles samples of different groups of fish under the current study were examined for aflatoxin residues (AOAC, 1995). $\mathrm{AFB}_{1}$ residues was extracted and analyzed by the method of Jemmali and Murthy(1976) using HPLC.

\section{9- Statistical analysis:}

The data collected were analyzed using statistical package social science procedure by SPSS (2006) for users guide; Means were statistically compared for the significance $(P \leq 0.05)$, using Duncan's multiple rang test.

\section{RESULTS AND DISCUSSION \\ 1-Chemical composion of the experimental diet:}

Chemical composition of the different experimental diets is shown in Table 2.

Table 2: Chemical Proximate analysis (\% DM basis) of the experimental diets

\begin{tabular}{|c|c|c|c|c|c|c|c|c|}
\hline \multirow{2}{*}{ Ingredients } & \multicolumn{8}{|c|}{ Diet No. } \\
\hline & 1 & 2 & 3 & 4 & 5 & 6 & 7 & 8 \\
\hline Dry matter & 91.92 & 91.17 & 91.54 & 91.27 & 90.92 & 91.15 & 91.45 & 90.97 \\
\hline Crude protein & 29.52 & 29.86 & 30.39 & 30.16 & 29.22 & 30.14 & 29.67 & 30.19 \\
\hline Ether extract & 5.91 & 5.87 & 6.04 & 6.51 & 5.89 & 6.01 & 6.19 & 5.94 \\
\hline Crude fiber & 3.39 & 3.14 & 3.06 & 3.62 & 3.44 & 3.51 & 3.48 & 3.89 \\
\hline Ash & 6.61 & 6.79 & 6.73 & 6.54 & 6.59 & 6.47 & 6.75 & 6.56 \\
\hline Nitrogen free extract & 54.57 & 54.34 & 53.78 & 53.17 & 54.86 & 53.87 & 53.91 & 53.42 \\
\hline \multicolumn{9}{|l|}{ Calculated energy value } \\
\hline GE (Kcal/100g) & 452.92 & 453.49 & 455.73 & 456.30 & 452.26 & 454.41 & 453.63 & 452.13 \\
\hline DE (Kcal/100g)" & 309.93 & 310.81 & 313.87 & 315.73 & 308.83 & 312.53 & 311.88 & 311.25 \\
\hline P/GE, mg/kcal"' & 65.17 & 65.84 & 66.68 & 66.09 & 64.60 & 66.32 & 65.40 & 66.77 \\
\hline
\end{tabular}

* Gross energy was calculated according to $\boldsymbol{N R C}(1993)$ by using factors of $5.65,9.45$ and 4.22 Kcal per gram of protein, EE and NFE, respectively.

** DE (Digestible energy) (Kcal/ $100 \mathrm{~g}$ ), based on $5.0 \mathrm{Kcal} / \mathrm{g}$ protein $9.0 \mathrm{Kcal} / \mathrm{g} \mathrm{EE}, 2.0 \mathrm{Kcal} / \mathrm{g}$ NFE. According to Wee and Shu. (1989).

*** $\mathrm{P} / \mathrm{GE}$ (protein to energy ratio) = crude protein $(\mathrm{mg}) / \mathrm{GE}(\mathrm{Kcal})$

Chemical analysis revealed that no differences were observed among all diets. The diets a were approximately isonitrogenous and isoenergetic. The CP content was between 29.22 to $30.39 \%$ on DM basis, and the GE values ranged between 452.13 and 456.30 $\mathrm{Kcal} / 100 \mathrm{~g}$, Such level was within the range suggested by NRC (1993) in the practical diets for tilapia. However, it was nearly similar to that used by Abdel-Maksoud et al. (1998). 


\section{2-Water quality parameters of rearing fish:}

Results of water quality parameters of the experimental aquaria are shown in Table 3, which were suitable for rearing Nile tilapia fingerlings as cited by Abdel -Hakim, et al. (2002) and Abdelhamid (2000b). In general, the water temperature of the different treatments were ranged between 26.2 and $27.3 \mathrm{C}^{\circ}$. $\mathrm{pH}$ values between 6.9 and 7.8 and dissolved oxygen between 5.1 and $6.3 \mathrm{mg} / \mathrm{L}$.

Similar results were reported by Abdelhamid et al. (2004) and Salem (2012). Average of nitrite $\left(\mathrm{NO}_{2}\right)$ and ammonia $\left(\mathrm{NH}_{3}\right)$ concentration ranged from 0.37 to $0.46 \mathrm{mg} / \mathrm{L}$ and from 0.04 to 0.06 $\mathrm{mg} / \mathrm{L}$, respectively. Which were suitable for rearing Nile tilapia as reported by Khalafalla and Mohsen (2007).

Table 3: Averages of some physic- chemical parameters of water

\begin{tabular}{|c|c|c|c|c|c|}
\hline \multirow{2}{*}{ Treat No. } & \multicolumn{5}{|c|}{ Water parameters } \\
\cline { 2 - 6 } & $\begin{array}{c}\text { Temperature } \\
\text { o- }\end{array}$ & $\begin{array}{c}\mathbf{p H} \\
\text { value }\end{array}$ & $\mathbf{D O} \mathbf{~ m g / l}$ & $\begin{array}{c}\mathbf{N H}_{\mathbf{3}} \\
\mathbf{m g} / \mathbf{l}\end{array}$ & $\mathbf{N O}_{\mathbf{2}}, \mathbf{m g} / \mathbf{l}$ \\
\hline T1 & 27.0 & 7.1 & 6.3 & 0.04 & 0.39 \\
\hline T2 & 26.4 & 7.6 & 5.1 & 0.05 & 0.44 \\
\hline T3 & 26.7 & 7.3 & 5.3 & 0.06 & 0.46 \\
\hline T4 & 27.1 & 7.8 & 5.7 & 0.04 & 0.39 \\
\hline T5 & 26.2 & 7.4 & 5.9 & 0.04 & 0.41 \\
\hline T6 & 27.3 & 6.9 & 6.1 & 0.05 & 0.37 \\
\hline T7 & 26.9 & 7.7 & 5.7 & 0.04 & 0.40 \\
\hline T8 & 26.5 & 7.3 & 6.0 & 0.04 & 0.42 \\
\hline
\end{tabular}

\section{3- Growth performance and survival rate:}

Data presented in Table 4 showed that aflatoxin B1 (AFB1) had negative effects $(P \leq 0.05)$ on fish growth performance. Even though, there were no significant $(P \geq 0.05)$ differences in the initial body weights among all treatment. Average weight gains (AWG), average daily gain (ADG) and specific growth rate (SGR) of the experimental fish were the best for the fish fed T1 (control). However, T8 (aflatoxin-contaminated diet plus $1 \mathrm{~g}$ Cap T2) and T6 (aflatoxincontaminated diet plus $1 \mathrm{~g}$ Filofed) were better than T2 (contaminated with aflatoxin $B_{1} 150 \mathrm{ppb}$ ). In general, the fish of $T 2$ recorded the lowest values for AWG, ADG, SGR and SR when compared to the other treatment. On the other hand, there were no significant differences between either fish fed diets T3, T4, T5 and T7. These results were in agreement with the finding of Abdelhamid (2008) who found that $\mathrm{AFB}_{1}$ at levels $100 \mathrm{ppb}$ and 150ppb in the diet of fish fingerlings without adding antitoxins caused a significant growth depression. This poor growth might be a result of expelling the feed from the mouth of fish (Nguyen et al., 2002). Also, the same results reported by Salem et al. (2009) who found a significant reduction in growth performance and survival rate of $O$. niloticus fish as affected by 
aflatoxin $\mathrm{B}_{1}$ (AFB1) in the diet. On the other hand, adding some medicinal plants and some spices to the contaminated diet reduced the toxic effect of the AFB1 and stimulated growth performance of the fish (El-Dakar et al. 2005 and Russo et al., 2013).

These results agreed with the findings reported by Salem et. al. (2010) and Salem (2012) who mentioned that AFB1 at levels of $100 \mathrm{ppb}$ and $150 \mathrm{ppb}$ significantly increased the mortality rate in tilapia. The ability of Rotamin and Power Top to decrease the mortality rate may be due to its constituents that stimulate the immune system (Piraret et al., 2006).

Table 4: The growth performance parameters and survival rates of the tilapia fish as affected by the dietary treatments (Mean* ${ }^{*}$ SE)

\begin{tabular}{|c|c|c|c|c|c|c|}
\hline Treat. & $\begin{array}{c}\text { Initial } \\
\text { weight } \\
\text { g/fish }\end{array}$ & $\begin{array}{c}\text { Final } \\
\text { weight } \\
\text { g/fish }\end{array}$ & $\begin{array}{c}\text { Total } \\
\text { weight gain } \\
\text { (TWG) } \\
\text { g/fish }\end{array}$ & $\begin{array}{c}\text { Average } \\
\text { daily gain } \\
\text { (ADG) } \\
\text { g/fish/day }\end{array}$ & $\begin{array}{c}\text { SGR \%/ } \\
\text { day }\end{array}$ & $\begin{array}{c}\text { Survival rate } \\
\text { (SR) \% }\end{array}$ \\
\hline \hline T1 & $20.03 \pm 0.04 \mathrm{a}$ & $49.22 \pm 0.25 \mathrm{a}$ & $29.19 \pm 0.20 \mathrm{a}$ & $0.29 \pm 0.00 \mathrm{a}$ & $0.91 \pm 0.00 \mathrm{a}$ & $98.03 \pm 1.96 \mathrm{a}$ \\
\hline T2 & $20.09 \pm 0.02 \mathrm{a}$ & $37.28 \pm 0.19 \mathrm{e}$ & $17.19 \pm 0.20 \mathrm{e}$ & $0.17 \pm 0.00 \mathrm{e}$ & $0.62 \pm 0.00 \mathrm{e}$ & $60.78 \pm 1.96 \mathrm{~d}$ \\
\hline T3 & $20.05 \pm 0.03 \mathrm{a}$ & $40.48 \pm 0.22 \mathrm{~d}$ & $20.42 \pm 0.20 \mathrm{~d}$ & $0.20 \pm 0.00 \mathrm{~d}$ & $0.71 \pm 0.00 \mathrm{~d}$ & $78.43 \pm 1.96 \mathrm{c}$ \\
\hline T4 & $19.99_{ \pm 0.03 \mathrm{a}}$ & $40.85 \pm 0.34 \mathrm{~d}$ & $20.86 \pm 0.34 \mathrm{~d}$ & $0.21 \pm 0.00 \mathrm{~d}$ & $0.72 \pm 0.00 \mathrm{~d}$ & $90.19 \pm 1.96 \mathrm{~b}$ \\
\hline T5 & $19.99 \pm 0.05 \mathrm{a}$ & $41.00 \pm 0.28 \mathrm{~d}$ & $21.01 \pm 0.26 \mathrm{~d}$ & $0.21 \pm 0.00 \mathrm{~d}$ & $0.72 \pm 0.00 \mathrm{~d}$ & $90.19 \pm 1.96 \mathrm{~b}$ \\
\hline T6 & $20.07 \pm 0.02 \mathrm{a}$ & $43.77 \pm 0.78 \mathrm{c}$ & $23.70 \pm 0.76 \mathrm{c}$ & $0.24 \pm 0.00 \mathrm{c}$ & $0.79 \pm 0.01 \mathrm{c}$ & $92.15 \pm 1.96 \mathrm{ab}$ \\
\hline T7 & $20.05 \pm 0.03 \mathrm{a}$ & $43.03 \pm 0.48 \mathrm{c}$ & $22.97 \pm 0.50 \mathrm{c}$ & $0.23 \pm 0.00 \mathrm{c}$ & $0.77 \pm 0.01 \mathrm{c}$ & $94.11 \pm 3.39 \mathrm{ab}$ \\
\hline T8 & $20.05 \pm 0.03 \mathrm{a}$ & $45.46 \pm 0.20 \mathrm{~b}$ & $25.41 \pm 0.21 \mathrm{~b}$ & $0.25 \pm 0.00 \mathrm{~b}$ & $0.83 \pm 0.00 \mathrm{~b}$ & $98.03 \pm 1.96 \mathrm{a}$ \\
\hline
\end{tabular}

\section{4-Feed intake and protein utilization:}

All criteria studied and presented in Table 5 showed that T1, T8and T6 were better $(P \leq 0.05)$ in comparison with the T2 group (containing AFB1) concerning FI, FCR, PER, and PPV\% in tilapia fish. On the other side, there was no significance difference between T1, T8 and T6 in data of FCR, PER, and PPV\%. The addition of Cap t2 was more effective compared to the other treatment. While, the addition of AFB1 (T2) had negative effect on all fish performance parameters (FI, FCR, PER, and PPV\%). Black pepper and coriandrum stimulates digestion and influences positively the terminal enzymes of digestive process (Abdel-Wahab et al., 2007, Salem et al., 2009 and Salem, 2012).

The present results agree with the findings of Nguyen et al. (2002) who reported a clear reduction in feed consumption in a direct relation to the dietary AFB1 level for $O$. niloticus. Those authors added

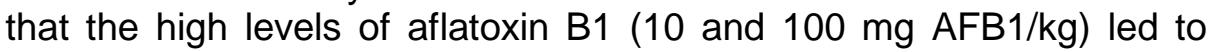
decrease feed intake. On the other hand, Svobodova et al. (1982) proved that AFB1 at doses of 20 to $200 \mathrm{mg} / \mathrm{Kg}$ of feed did not show any effects on feed and protein utilization. Also, Aly and Mohamed 
(2010) concluded that, garlic supplemented diets has immuno stimulation for tilapia ( $O$. niloticus) and improved feed intake, body weight and body weight gain than the groups fed diet with aflatoxin.

Table 5: Feed intake and feed and protein utilization of Nile tilapia fish as affected by the dietary treatments $\left(\mathrm{Mean}^{*}+\mathrm{SE}\right)$

\begin{tabular}{|c|c|c|c|c|}
\hline Treat. & Feed Intake $\mathbf{( g )}$ & FCR & PER & PPV\% \\
\hline \hline T1 & $74.48 \pm 0.32 \mathrm{a}$ & $2.55 \pm 0.00 \mathrm{e}$ & $1.32 \pm 0.00 \mathrm{a}$ & $36.68 \pm 1.92 \mathrm{a}$ \\
\hline T2 & $64.32 \pm 0.19 \mathrm{e}$ & $3.74 \pm 0.03 \mathrm{a}$ & $0.89 \pm 0.00 \mathrm{e}$ & $17.05 \pm 1.33 \mathrm{~d}$ \\
\hline T3 & $66.56 \pm 0.22 \mathrm{~d}$ & $3.25 \pm 0.02 \mathrm{~b}$ & $1.00 \pm 0.00 \mathrm{~d}$ & $20.25 \pm 3.08 \mathrm{bc}$ \\
\hline T4 & $67.51 \pm 0.08 \mathrm{c}$ & $3.23 \pm 0.05 \mathrm{~b}$ & $1.02 \pm 0.01 \mathrm{~d}$ & $22.62 \pm 2.33 \mathrm{bc}$ \\
\hline T5 & $67.91 \pm 0.17 \mathrm{c}$ & $3.23 \pm 0.04 \mathrm{~b}$ & $1.05 \pm 0.01 \mathrm{~cd}$ & $26.22 \pm 0.70 \mathrm{~b}$ \\
\hline T6 & $69.80 \pm 0.22 \mathrm{~b}$ & $2.95 \pm 0.09 \mathrm{~cd}$ & $1.12 \pm 0.03 \mathrm{bc}$ & $18.10 \pm 1.23 \mathrm{~cd}$ \\
\hline T7 & $69.77 \pm 0.23 \mathrm{~b}$ & $3.03 \pm 0.06 \mathrm{c}$ & $1.10 \pm 0.02 \mathrm{bc}$ & $39.25 \pm 2.40 \mathrm{a}$ \\
\hline T8 & $71.88 \pm 0.18 \mathrm{~b}$ & $2.82 \pm 0.02 \mathrm{~d}$ & $1.17 \pm 0.00 \mathrm{~b}$ & $23.73 \pm 2.11 \mathrm{bc}$ \\
\hline
\end{tabular}

$a, b, c, d$ and e means in the same column bearing different letters differ significantly at 0.05 level.

\section{5- proximate chemical analysis of the whole fish body:}

The proximate chemical analysis of the whole body of the tested tilapia fish is given in Table 6 . The control and T8 diets had the higher $(\mathrm{P} \leq 0.05)$ DM content compared with the other treatment. while, the fish fed T2 had the lowest DM content. There were significant differences among the dietary treatments for CP contents. The highest CP was observed in the fish groups T7, T5, and T8 and lowest values were in groups T2, T3, T4, and T6. The differences were significant $(P \leq 0.05)$ for $E E$ and ash in the all treatments. Generally, the addition of black pepper, filofeed plus and cap $t_{2}$ improved proximate analysis of fish carcass.

Table 6: Proximate Chemical analysis (\% DM basis) and energetic value of the whole tilapia body as affected by the experimental diets (Mean*+ SE)

\begin{tabular}{|l|c|c|c|c|c|}
\hline \multirow{2}{*}{$\begin{array}{c}\text { Treat. } \\
\text { No }\end{array}$} & & \multicolumn{5}{c|}{$\%$ On Dry matter basis } \\
\cline { 2 - 6 } & DM\% & CP\% & EE\% & Ash\% & $\begin{array}{c}\text { EC } \\
\text { (K*al } / 100 g)\end{array}$ \\
\hline \multicolumn{7}{|c|}{ At the start of the experiment } \\
\hline \multicolumn{7}{|c|}{$23.61 \pm 0.01 \mathrm{e}$} & $59.61 \pm 0.23 \mathrm{e}$ & $10.33 \pm 0.02 \mathrm{e}$ & $22.55 \pm 0.22 \mathrm{a}$ & $423.15 \pm 1.13 \mathrm{~d}$ \\
\hline At the end of the experiment \\
\hline T1 & $27.82 \pm 0.07 \mathrm{a}$ & $67.68 \pm 0.25 \mathrm{a}$ & $17.44 \pm 0.31 \mathrm{c}$ & $16.21 \pm 0.09 \mathrm{e}$ & $535.90 \pm 4.39 \mathrm{a}$ \\
\hline T2 & $25.33 \pm 0.14 \mathrm{~d}$ & $62.89 \pm 0.20 \mathrm{~d}$ & $21.22 \pm 0.24 \mathrm{a}$ & $16.38 \pm 0.20 \mathrm{e}$ & $544.61 \pm 2.77 \mathrm{a}$ \\
\hline T3 & $25.68 \pm 0.16 \mathrm{~cd}$ & $63.71 \pm 0.37 \mathrm{~cd}$ & $19.32 \pm 0.34 \mathrm{~b}$ & $20.40 \pm 0.23 \mathrm{~b}$ & $531.30 \pm 3.96 \mathrm{ab}$ \\
\hline T4 & $27.61 \pm 0.33 \mathrm{ab}$ & $64.22 \pm 0.30 \mathrm{bc}$ & $20.25 \pm 0.48 \mathrm{a}$ & $19.16 \pm 0.24 \mathrm{~b}$ & $542.92 \pm 3.54 \mathrm{a}$ \\
\hline T5 & $26.16 \pm 0.04 \mathrm{c}$ & $64.82 \pm 0.10 \mathrm{~b}$ & $16.07 \pm 0.39 \mathrm{~d}$ & $17.14 \pm 0.16 \mathrm{~cd}$ & $506.79 \pm 3.49 \mathrm{c}$ \\
\hline T6 & $27.40 \pm 0.07 \mathrm{bc}$ & $63.42 \pm 0.46 \mathrm{~cd}$ & $17.30 \pm 0.62 \mathrm{c}$ & $17.26 \pm 0.25 \mathrm{c}$ & $510.56 \pm 5.14 \mathrm{c}$ \\
\hline T7 & $27.22 \pm 0.02 \mathrm{bc}$ & $67.74 \pm 0.45 \mathrm{a}$ & $15.75 \pm 0.63 \mathrm{~d}$ & $16.48 \pm 0.33 \mathrm{~d}$ & $520.30 \pm 8.21 \mathrm{bc}$ \\
\hline T8 & $27.98 \pm 0.22 \mathrm{a}$ & $64.31 \pm 0.46 \mathrm{~b}$ & $17.37 \pm 0.17 \mathrm{c}$ & $17.49 \pm 0.19 \mathrm{c}$ & $518.84 \pm 3.04 \mathrm{bc}$ \\
\hline
\end{tabular}

${ }^{*}$ Means superscripted (in the same column) with different letters significantly ( $\left.\leq \leq 0.05\right)$ differ.

${ }^{* *} \mathrm{EC}=$ Calculated energy content. 
Similar results were reported by Salem (2002) who found that the percentages of DM and CP decreased as the levels of the aflatoxin $\mathrm{B} 1$ increased, while the values of $\mathrm{EE}$ and ash increased with increasing the levels of AFB1. Additionally, Abdelhamid et al. (2004 and 2006) and Mehrim et al. (2006) concluded that aflatoxin B1 significantly reduced $\mathrm{DM}$ and $\mathrm{CP}$ content of the $O$. niloticus fish carcass, but it significantly increased $\mathrm{EE}$ and ash content of the fish. Also, Salem (2012) found high significant ( $P \leq 0.05)$ differences among the dietary treatments in $\mathrm{CP}, \mathrm{EE}$ and ash contents. The highest CP was observed in the fish groups of T1, T3, T4, T5 and T6 and the lowest values were found in groups T2. The highest EE was observed in the fish group of T2.

\section{6-Internal organ indices:}

Significant $(\mathrm{P} \leq 0.05)$ differences were found among the dietary treatments for kidney- somatic index (KSI), hepato -somatic index (HSI), and spleen -somatic index (SSI) as presented in Table 7.

Generally, from the results in the present study, treatment (T2) caused negative effects on the internal organs indices comparing with the control diet (T1) and the other treatments (T3,T4, T5, T6, T7 and T8). This means that AFB1 not only reduced growth performance of the tested fish, but also negatively altered internal organs function as a consequence of affecting their relative weights, which may be due to changing in their cells number or volume or elevating their water and / or blood contents (Glaister, 1986, Abdelhamid et al., 2006 and Mehrim et al., 2006).

Hussein et al. (2000) observed that hepato - somatic index (HSI) was increased by increasing AFB1 level in the diet of $O$. niloticus but gonado - somatic index (GSI) decreased. Abdelhamid et al. (2006) , Salem et al. (2009) and Salem (2012) reported that the aflatoxic diet at a level of $100 \mathrm{ppb}$ AFB1 led to significant increases $(P \leq 0.05)$ in all organs indices comparing with the control diet (zero ppb AFB1). However, Zychowski et al. (2013) and El-Barbary and Mohamed (2014). found that HSI was decreased significantly in groups exposed to AFB1.

On the other hand, Abdelhamid et al. (2006) found that the additives (tafla, ammonia and hydrogen peroxide) did not alter the organs weigh; yet, they slightly diminished -to some extent - the negative effect of dietary aflatoxin inclusion on the relative weights of all tested organs. Also, Shehab el-din et al. (2013) recently added that the additives of $(0.2 \%$ Rotamin and $0.3 \%$ Power top) as antimycotoxins for Nile tilapia rations caused decrease in hepato somatic indices comparing with the aflatoxin B1 contaminated diet. In the present study, the effects of biological(Cap T2) and chemical 
(Filofed plus) additives may be due to increase of immunity of fish, reduced the effect of the toxin of AFB1 and hence hide its negative effects on indices of fish. Additionally, Zychowski et al. (2013) and ElBarbary and Mohamed, (2014) found that the HSI was decreased significantly in groups exposed to AFB1.

Table 7: Internal organs indices of the tilapia fish at the end of experimental period as affected by the experimental diets (Means ${ }^{*} \pm \mathrm{SE}$ )

\begin{tabular}{|c|c|c|c|}
\hline Treat. & HSI\% & KSI\% & SSI\% \\
\hline \hline T1 & $2.94 \pm 0.02 \mathrm{e}$ & $0.31 \pm 0.01 \mathrm{e}$ & $0.29 \pm 0.00 \mathrm{~d}$ \\
\hline T2 & $4.12 \pm 0.01 \mathrm{a}$ & $0.53 \pm 0.02 \mathrm{a}$ & $0.51 \pm 0.02 \mathrm{a}$ \\
\hline T3 & $3.44 \pm 0.00 \mathrm{~b}$ & $0.43 \pm 0.01 \mathrm{bc}$ & $0.45 \pm 0.02 \mathrm{~b}$ \\
\hline T4 & $3.39 \pm 0.01 \mathrm{bc}$ & $0.45 \pm 0.01 \mathrm{~b}$ & $0.28 \pm 0.01 \mathrm{~d}$ \\
\hline T5 & $3.36 \pm 0.01 \mathrm{c}$ & $0.43 \pm 0.02 \mathrm{bc}$ & $0.40 \pm 0.00 \mathrm{bc}$ \\
\hline T6 & $3.14 \pm 0.01 \mathrm{~d}$ & $0.41 \pm 0.00 \mathrm{bc}$ & $0.29 \pm 0.01 \mathrm{~d}$ \\
\hline T7 & $3.19 \pm 0.03 \mathrm{~d}$ & $0.39_{ \pm}+0.01 \mathrm{~cd}$ & $0.39 \pm 0.03 \mathrm{c}$ \\
\hline T8 & $3.00 \pm 0.00 \mathrm{e}$ & $0.34 \pm 0.01 \mathrm{~d}$ & $0.36 \pm 0.00 \mathrm{c}$ \\
\hline
\end{tabular}

* Means superscripted (in the same column) with different letters differ significantly at 0.05 level.

\section{7-Residues of aflatoxin in the fish body:}

The residues of aflatoxin (AFB1) in the viscera and muscles of fish in the different experimental groups are shown in Table 8. The group fed AFB1 contaminated diet (150 ppb) T2 without any feed additives, showed the highest level (18.0 ppb aflatoxin B1) in viscera, followed by the group fed AFB1 contaminated with Black pepper, Filofed plus and Cap T2 which were 5.2, 7.2, 4.6, 5.4, 2.6 and 3.1 ppb for T3, T4, T5, T6, T7 and T8, respectively in viscera. So, T7 was the best treatment in reducing these residues. However, in muscles, the residues was detected only in the group fed on AFB1 contaminated diet (150 ppb) T2 without any feed additives (4.2 ppb) and did not detect in the other groups.

In this respect, Abdelhamid et al. (2004) reported that AFB1 residues in the $O$. niloticus flesh showed a cumulative effect related to the levels of dietary AFB1 and feeding period. Also, Soliman et al. (1998) mentioned that the significant increase of aflatoxin residues was observed in $O$. niloticus fish after 6 months. Abdelhamid et al. (2004), Salem et al. (2009) and Salem (2012) recorded residues of AFB1 in the whole body of $O$. niloticus at the end of the experiment and tended to decrease after a freezing period.

The residual AFB1 level in the liver was much higher than that in muscle fed the same contaminated diet with aflatoxin B1(Bintvihok et al., 2002 and El- Sayed and Khalil, 2009). Similar result was concluded by Arafa et al. (2014) 
No AFB1 residue in muscles was found in tilapia that treated by spices (black pepper), chemicals (Fiofed-plus) and biological (Cap T2) in the present study. This agreed with the results reported by Lim et al. (2001) and Usanno et al. (2005).

Table 8: The residues of aflatoxin B1in the tilapia fish wet weight basis as affected by the dietary treatments (Means * \pm SE)

\begin{tabular}{|c|l|l|c|c|c|c|c|c|}
\hline AFB1 in whole & \multicolumn{10}{|c|}{ Treatment } \\
\cline { 2 - 10 } body fish (ppb) & T1 & T2 & T3 & T4 & T5 & T6 & T7 & T8 \\
\hline Muscles & ND & 4.2 & ND & ND & ND & ND & ND & ND \\
\hline Viscera & ND & 18 & 5.2 & 7.2 & 4.6 & 5.4 & 2.6 & 3.1 \\
\hline
\end{tabular}

\section{8-Musculature and abdominal areas:}

The variation among the tested fish treatments, concerning musculature and abdominal areas are presented in Table 9 and Figs.1, 2, 3, 4, 5, 6, 7, and 8. The fish fed T2 (AFB1 without any additives) had the lowest musculature and abdominal area while the control and all the diets supplemented with feed additives had wider musculature and abdominal area and the control, T7 and T8 were more effective. These results agreed with the finding reported by Salem et al. (2009) and Salem (2012) who mentioned that AFB1 at levels of $100 \mathrm{ppb}$ and $150 \mathrm{ppb}$ increased significantly the abdominal cavity (black area) and decreased the musculature (white area) in tilapia.

Table 9: Musculature and abdominal area

\begin{tabular}{|l|l|l|l|l|l|l|l|l|}
\hline \multirow{2}{*}{ Items. } & \multicolumn{7}{|c|}{ Treat No. } \\
\cline { 2 - 8 } & $\mathrm{T} 1$ & $\mathrm{~T} 2$ & $\mathrm{~T} 3$ & $\mathrm{~T} 4$ & $\mathrm{~T} 5$ & $\mathrm{~T} 6$ & $\mathrm{~T} 7$ & $\mathrm{~T} 8$ \\
\hline $\begin{array}{l}\text { Musculature } \\
\text { area mm }\end{array}$ & 34.3 & 25.4 & 27.2 & 27.2 & 28.3 & 29.0 & 32.7 & 33.6 \\
\hline
\end{tabular}

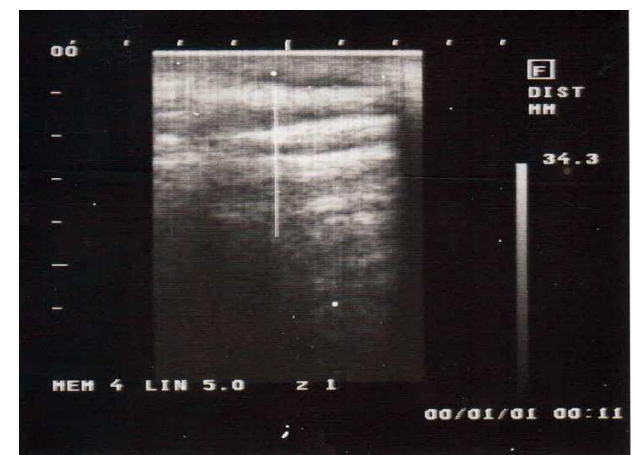

Fig.(1) Diet 1 (Control) Musculature area about 34.3

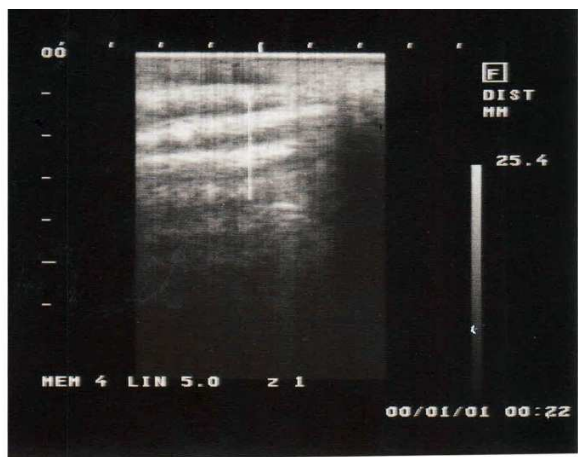

Fig.(2) Diet 2 (AFB1 without any additives ) Musculature area about 25.4 


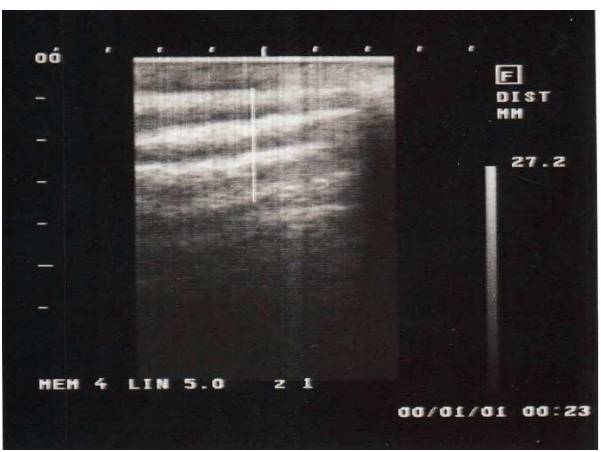

Fig.(3) Diet 3 (AFB1 $+0.5 \mathrm{~g}$ of Black pepper)

Musculature area about 27.2

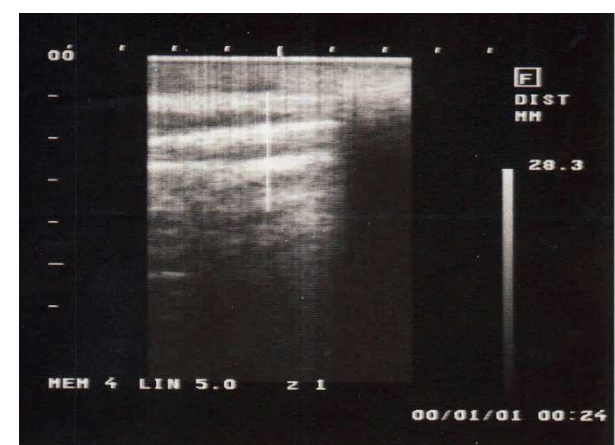

Fig.(5) Diet 5 (AFB1 + 0.5g of Filo feed plus)

Musculature area about 28.3

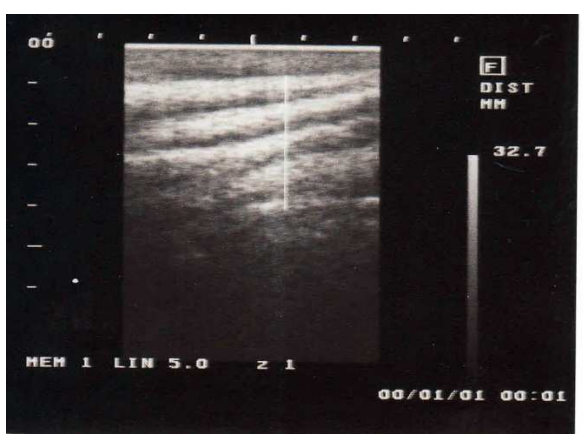

Fig.(7) Diet 7 (AFB1 $+0.5 \mathrm{~g}$ of Cap T2) Musculature area about 32.7

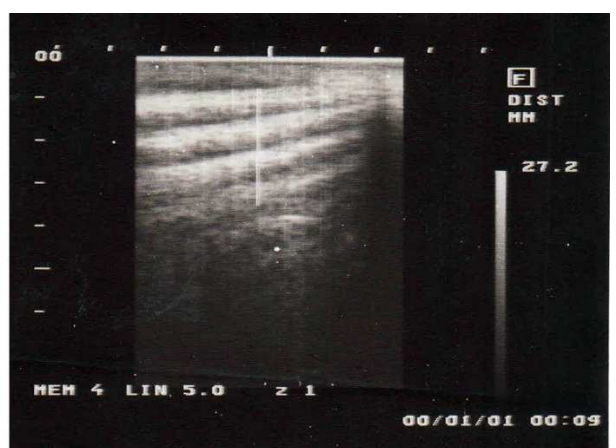

Fig.(4) Diet 4 (AFB1 $+0.1 \mathrm{~g}$ of Black pepper)

Musculature area about 27.2

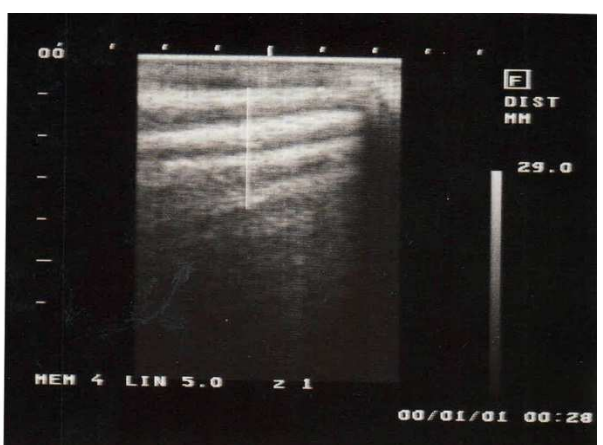

Fig.(6) Diet 6 (AFB1 $+0.1 \mathrm{~g}$ of Filo feed plus)

Musculature area about 29.0

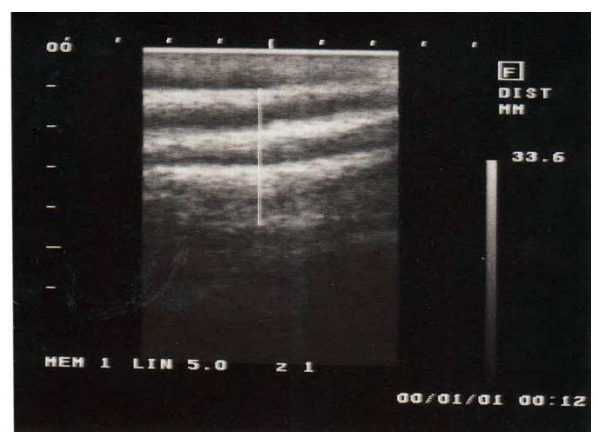

Fig.(8) Diet 8 (AFB1 $+0.1 \mathrm{~g}$ of Cap T2)

Musculature area about 33.6 


\section{CONCLUSIONS}

From the foregoing results it could be concluded that aflatoxin contaminated diets caused many drastic effects in all tested parameters. Adding Black pepper (spices), Filofeed plus (chemicals) and Cap T2 (biological) at both levels ( 0.5 and $1 \mathrm{~g}$ ) to the diets of Nile tilapia showed positive effects on all fish performance parameters as well as alleviate the toxic effects of AFB1 contaminated diets. Moreover, it is needed a lot of scientific efforts in this trend to use of the natural agents to detoxify mycotoxin (particularly aflatoxin) in diets of fish.

\section{REFERENCE}

A. O. A. C. Association of Analytical Chemists, (1995) Methods of Analysis, Washington D. C. USA.

Abd El - Hakim, N. F.; Bakeer, M. N. and Soltan, M. A. (2002). Water Environment for Fish Culture. Deposition NO: 4774, ISBN:977-298228-5.

Abd El -Maksoud, A. M.; Allam, S. M.; Abou- Fotoh, G. E.; and Abou Zied, R. M. (1998). Evaluation of Nigella seeds as a feed additives in diets of Nile tilapia. Fayoum. J. Agric. Res. \& Dev. 12: 170-181.

Abdelhamid, A. M.; Nemetallah, B. R.; Abd Allah, M. A. and Mousa, T. A. E. (2006). Hemalytic activity in blood serum of Oreochromis niloticus under different types of stress. The $3^{\text {rd }}$ Int. Conf. for Develop, and the Env. in the Arab World, March 21 -23, Assuit Univ., pp.: 153- 169.

Abdelhamid, A. M. (1989). Contamination of feeding stuffs with mycotoxins and the dangers creating from these contaminants. $1^{\mathrm{ST}}$ Meeting on Animal Nutrition, Assuit Univ., November, pp.: $39-75$.

Abdelhamid, A. M. (2000b). Scientific Fundamentals of Fish Production and Husbandry. $2^{\text {nd }}$. Ed., Mansoura faculty of agriculture.

Abdelhamid, A. M. (2008). Thirty years (1978-2008) of mycotoxin research at faculty of agriculture, AL Mansoura University, Egypt. Engormix.com, Mycotoxins Technical Articles, 11p.

Abdelhamid, A. M. and Saleh, M. R. M. (1996). Are Aflatoxin and Ochratoxin endemic mycotoxins in Egypt. Proc. Conf. Food Borne Contamination \&Egyptians Heath, Mansoura Univ., Nov. 26 -27 , pp.51 59.

Abdelhamid, A. M.; Ahmad, A. A. and EL- Meleigy, Kh. M. (2004). An attempt to alleviate the histological alterations of some internal organs of rats fed on aflatoxin contaminated diets. J. Agric. Sci. Mansoura Univ., 24: 2355-2370.

Abdelhamid, A. M. and Mahmoud, K. I. (1996). Elimination or adsorption of aflatoxin from poultry feedstuffs. Proc. Conf. Foodborne Contamination \& Egyptian's Health, Mansoura Univ., 26- 27 Nov., pp. 61-69.

Abdelhamid, A. M.; Khalil, F. F. and Ragab, M. A (1998). Problem of mycotoxins in fish production. Egypt J. Nutr. Feeds, 1 (1): $63-71$. 
Abdelhamid, A. M.; Mehrim, A. I. and Khalil, F. F. (2004). Detoxification of aflatoxin- contaminated diet of tilapia fish using dietary supplementation with egg shell, Betain ${ }^{\circledR}$, clay or silica. J. Agric. Sci. Mansoura Univ., 29: 3163-3174.

Abdel-Wahhab, M. A.; Omara, E. A.; Abdel-Galil, M. M.; Hassan, N. S.; Nada, S. A.; Saeed, A. and El-Sayed, M.M. (2007). Zizyphus SpinaChristi extract protects against aflatoxin B1-inhibited hepatic carcinogenicity. Afr. J. Trad. CAM, 4 (3): 248-256.

Alabaster, J. S.; and Lioyd, R. (1982). Water Quality Criteria for Fresh Water Fish. Second Edition. Bulter Work Scientific, London.

Arafa, M. M.; Ali, A. T.; and Mohammed, F. Samia. (2014). Detecting the effect of Aflatoxin B1 polluted rations on freshwater fish, Lates niloticus reared in fish culture ponds. Current Science International, 3 (1): 34-39.

Bintvihok, A.; Thiengnin, S.; Doi, K.; and Kumagai, S. (2002). Residues of aflatoxin in the liver, muscle and eggs of Domestic Fowls. J. Vet. Med. Sci., 64: $1037-1039$.

CAST Report (2003). Mycotoxins risks in plant, animal and human systems Council for Agricultural Science and Technology Task Force Report No. 139, Ames, lowa, USA, ISBN 1 - 887383 - 22 -0. 2742.

Conner, D. E. (1993). Naturally occurring compounds. In: Davidson, P. L., Branem, A. L. (Eds.), Antimicrobials in Foods. Marcel Dekker, New York, pp. 441-468.

El-Dakar, A. Y.; Shymaa, A. Y.; Shalaby, M.; Abead, S. M.; and Khalafala (2005). Use of as feeding stimulation in diets of marine shrimp penaeus japonicas. Egypt ion. J. Nutrition and Feed, 8 (1) Special Issue: 1065 - 1076.

El-Fiky, S. A. and Zaki, V. H. (1994). Genotoxic and pathological effects of aflatoxin $\mathrm{B}_{1}$ contaminated diet of Oreochromis niloticus. Alex. J. Vet. Science, 13: 159-170.

El-Sayed, Y. S.; and Khalil, R. H. (2009). Toxicity, biochemical effects and residue of aflatoxin $B 1$ in marine water - reared sea bass (Dicentrachus Labrax L.). Food Chem. Toxicol., 47: 1606-1609.

FAO, Food and Agriculture Organization of the United Nation(2002). Evaluation of Certain Mycotoxins in Food: Fifty - sixth Report of the Joint FAO / WHO Expert Committee on food Additives, World Health Organization, Geneva.

Farr, D. F.; Billis, G. F., Chamuris, G. P. and Rossman, A. Y. (1989). Fungi on plants and plant products in the united states.. American Phytopathological Society Press, St. Paul, MN, pp. 1-152.

FTU (2007). Feed Technology Update. Insects offer a promising solution to the protein bottle neck Volume 2 Issue 6.

GAFRD (2007). General authority for fish resources development. Fishery statistic. Egyptian Ministry of Aquaclture.

Glaister, J. R. (1986). Principles of Toxicological Pathology. Taylor \& Francis, London and Philadelphia. 
Hussein, S. Y.; Mekkawy, I. A.; Mokhtar, Z. Z. and Mubarak, M. (2000). Protective effect of Nigella sativa seed against aflatoxicosis in Oreochromis niloticus. Proc. Conf. Mycotoxins and Dioxins and the Environment, Bydgoszcz, 25 -27 Sept., pp.: 109 - 130.

Ioannou - Kakouri, L.; Aletrali, A.; Christou, E.; Hadjioannou - rally, A.; Koliou, A. and Akkeliddou, D. (1999). Surveillance and control of aflatoxins B1, B2, G1, G2 and M1 in foodstuffs in the Republic of Cyprus:v1992 - 1996. J. AOAC. Int., 82: 883 - 892.

Jangaard, P. M.; Ackman, R. G. and Spios, J. C. (1967). Seasonal studies of the fatty acids composition of cod liver flesh, roe and milt lipids. J. Fish. Res. Bd. of Canada, 24: 613-627.

Jemmali, M. and Murthy, T. R. K. (1976). A chemical assay method for the determination of aflatoxin residues in animal tissues. $Z$. Lebensm. Unters. Forsch. 161, 13-17.

Khalafalla, M. M. E. and Mohsen, M. K. (2007). Influence of some medicinal plants supplementation as a feed additives on growth and feed utilization in diets of Nile tilapia (Oreochromis niloticus) fingerlings. Egypt. J. Aquat. Biol. \& Fish, 11: 213-229.

Lim, H., Ng, W., Lim, S. and Ibrahim, C. O. (2001). Contamination of palm kernel meal with Aspergillus flavus affects its nutritive value in pelleted feed for tilapia, Oreochromis mossambicus. Aquaculture Research, 32: 895 - 905.

Mehrim, A. I.; Abdelhamid, A. M.; Abo Shosha, A. A.; Salem, M. F. I. and El-Sharawy. M. A. (2006). Nutritious Attempts to Detoxify Aflatoxic Diets of Tilapia Fish 2- Clinical, Biochemical and Histological Parameters Journal of the Arabian Aquaculture Society, 1 (2). 6990.

N. R. C. National Research council. (1993). Nutrition requirements of warm water fishes and shellfishes National Research Council, National Academy of science, Press Washington, DC, USA

Nayek, S. K.; Swain, P. and Mukherjee, S. C. (2007). Effect of dietary supplementation of probiotic and vitamin $C$ on the immune response of Indian major carp, Labeo rohta (Ham.). Fish \& Shellfish Immunol., 23 (4): $892-896$.

Nguyen, A. T.; Grizzle, J. M.; Lovell, R. T.; Manning, B. B. and Rottinghaus, F.G. (2002). Growth and hepatic lesions of Nile tilapia Oreochromis niloticus fed diets containing aflatoxin B1. Aquaculture, 212: 311- 319.

Russo, J. A. R. and Yanong, R. P. E. (2013). Molds in fish feeds and aflatoxicosis. University of Florida, IFAS Extension FA, 95: 1-3.

Sahoo, P. K. and Mukheriee, S. C. (2003). Immunomodulation by dietary vitamin $C$ in healthy and aflatoxin B1 - induced immunocompromised Indian major carp Labeo rohita. Comparative Immunology, Microbiology\& Infectious Dieases, 26: $12-65$.

Salem, M. F. I. (2008). Replacement of fish meal by silkworm, Bombyx mori Pupa meal, in Nile tilapia, O. niloticus diets. Egyptian. J. Nutrition and feeds. 11 (3): 611-624. 
Salem, M. F. I. (2012). An attempt for reduction aflatoxicosis B1 in Nile tilapia (O. niloticus) through medicinal plant. Egyptian. J. Nutrition and feeds. 15 (1): 203-213.

Salem, M. F. I; Abd El-Raouf, E. M.; Eweedah, N. M. and Mohamed, B. S. (2009). Influence of some medicinal plants as antimycotoxins in Nile tilapia (O. niloticus) diets. Proc. Conf. Fish production. Oct., 5, pp. 10-26.

Shalaby, S. M. M., (2004). Response of Nile tilapia, fingerlings to diets supplemented with different levels of fenugreek seed. J. Agric. Mansoura Univ., 29: 2231-2242.

Shehab el-din, M. T.; Guda, A. H .; Salem, M. F. I. and El-komy H. M. (2013). Studies on some prebiotics as antimycotoxins for Nile tilapia rations. J. Agric. Res. Kafr El-Sheikh Univ. 39 (1) 2013.

Soliman, K. M.; Ayesh, A. M.; Essa, M. A. M. and Naguib, K. (1998). FixA-tox in aquaculture: 1-Effect of aflatoxin decontamination by a selective chemisorbent materials on the Oreochromis niloticus with considering fish processing efficiency . J . Egypt. Ger. Soc. Zoot., .25 (A) Comparative Physiology, 1-19.

SPSS (2006). Statistical package for the social sciences, Versions15, command syntax reference. No 2006 inc., Chicago, IL, USA.

Svobodova, Z.; Piskac, A.; Havilikova , J. and Groch, L. (1982 ). The influence of feed with different contents of aflatoxin B1 on carp health condition . Zivotisna Vyroba ., 27 : 811-820.

Sweeney, M. J. and Dobson. A. D. W. (1998). Mycotoxin production by Aspergillus, Fusarium and Penicillum species. (A Review) Int. J. of Food Microbiology, 43: 145-158.

Usanno, O.; Chaisilapasung, S.; Sukrakanchana, N.; and Supamattaya, K. (2005). Effect of aflatoxin B1on sex reversed red tilapia (Oreochromis niloticus) Linn. $\times 0$. mossambicus Peters Songklanakarin. J. Sci. Technol. 27 (Suppl. 1), 187-197.

Wee, K. L. and Shu, S. W. (1989). The nutritive value of boiled feed -fat Soy bean in pelted feed for Nile tilapia. Aquaculture, 81: 303-314.

Zaky, Z. M.; Sharkawy, A. A.; Mubarak, M. and Ahmed, A. I. (2000). Effect of some immunstimulants on aflatoxicosis in ducks. Proc. Conf. Mycotoxins and Dioxins and the Environment, Bydgoszcz., 25 - 27 Sep., pp. 93 - 104

Zychowski, K. E.; Pohlenz, C.; Mays, T.; Romoser, A.; Hume, M.; Buentello, A.; Gatlin, D. M. and Phillips, T. D. (2013). The effect of Nova Sil dietary supplementation on the growth and health performance of Nile tilapia (Oreochromis niloticus) fed aflatoxinB1 contaminated feed. Aquaculture, 376: 117-123.

Aly, R. S. and Mohamed, M. (2010). Effect of Nigella sativa on ingesion ability of mice peritoneal macrophages. Saudi Pharma. J., 1: 18.

Piraret, N.; Kabayashi, T.; Katagiri, T.; Maita, M. and Endo, M. (2006). Protective effects. And mechanisms of a probiotic bacterium Lactobacillus Rhamnosus against experimental Edwardsiella. Tarda infection in Tilapia (O.niloticus). Veterinary-Immunology and Immunopathology, 113(3/4): 339-347. 
Salem, M. F. I. (2002). Effect of dietary graded levels of aflatoxin B1 on growth performance and chromosomal behavior of Nile tilapia ( $O$. niloticus) diets. PhD. Thesis. Kafr El-sheikh,Tanta Univ.

Salem, M.F.I., Abd El-Raouf, E.M., Eweedah, N.M., and. Mohamed B. S (2010). Influence of some medicinal plants as anti-mycotoxins in Nile tilapia (O. niloticus) diets. Proc. Global Fisheries\&Aquaculture Research Conf., 24-26 October, pp 227-242.

El-Sayed, A. F. M.; Ezzat, A. A.; Mansour, C. R. (2005). Effects of dietary lipid source on spawning performance of Nile tilapia (Oreochromis niloticus) brood stock reared at different water salinities. Aquaculture, 248:187-196.

El-Barbary, I. Manal and Mahmoud H. M. (2014) Chemoprevention and Therapeutic Efficacy of Glutathione Against Aflatoxicosis in Nile Tilapia (Oreochromis niloticus). Global Veterinaria 13 (6): 11111121.

$$
\begin{aligned}
& \text { الملخص العربي } \\
& \text { إزالة التلوث بالسموم الفطرية الافلاتوكسين بواسطة الطرق الكيماوية ، }
\end{aligned}
$$

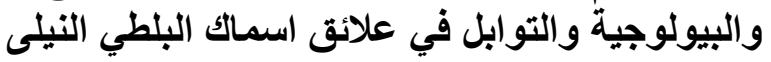

فوزى ابراهيم معجوز1 نبيل محمد عويضة 1، 1،حمود فؤاد سالم 2 ، ،عاصم على عامر2

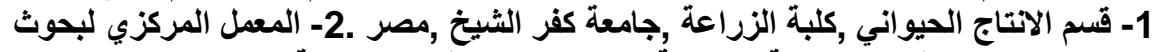

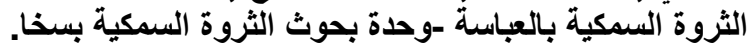

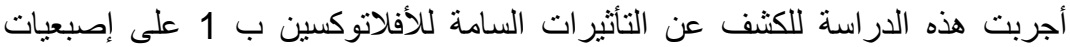

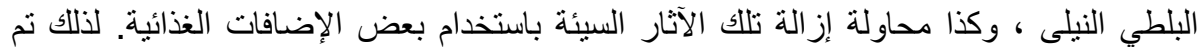

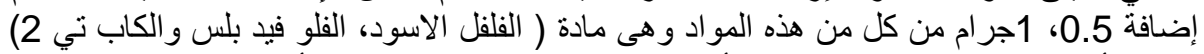

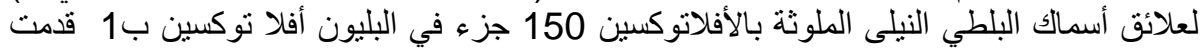

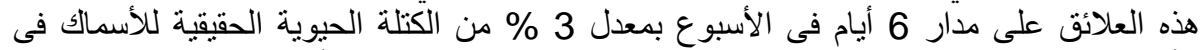

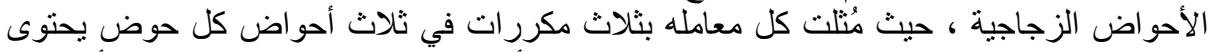

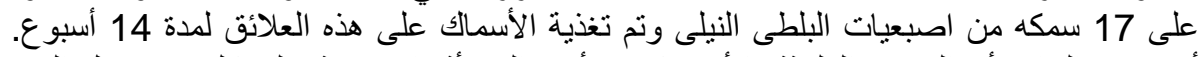

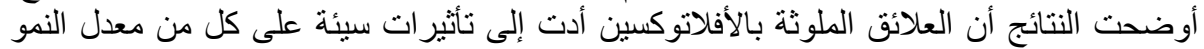

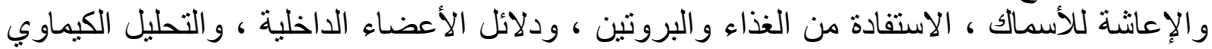

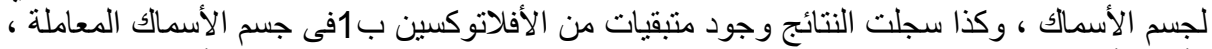

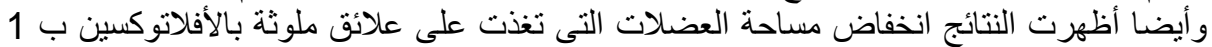

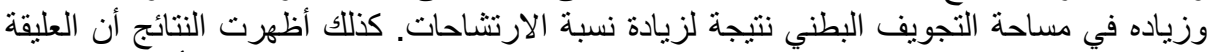

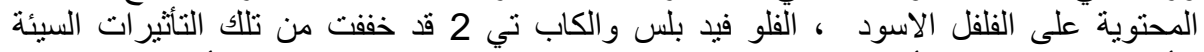

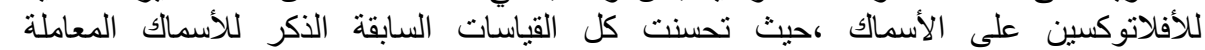

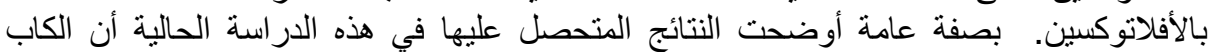

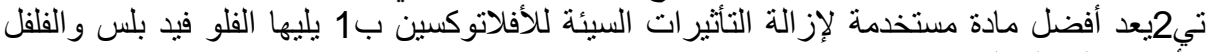
الأسمر على التوالي. 